\title{
Saint Nicolas' Church on the Czwartek Hill in view of current research
}

\author{
Krzysztof Janus \\ https://orcid.org/0000-0002-5391-3140 \\ k.janus@pollub.pl
}

Department of Architecture Urban Planning and Spatial Development, Faculty of Construction and Architecture, Lublin University of Technology

\section{Karol Krupa \\ https://orcid.org/0000-0002-7313-4080 \\ k.krupa@pollub.pl}

Department of Contemporary Architecture, Faculty of Construction and Architecture, Lublin University of Technology

\begin{abstract}
The paper describes known and unknown research works, which took place in the building of Saint Nicolas' Church on the Czwartek Hill at the M. Słowikowskiego 1 street in Lublin, starting from the 1960s up to the present day. The paper introduce an interdisciplinary way description and presentation of the changes in the structure of the church, phases of transformations and shows the places where older objects could exist before church in current shape.
\end{abstract}

Keywords: Saint Nicolas' Church on the Czwartek Hill, architectural studies, georadar

\section{Saint Nicolas' Church on the Czwartek Hill in view of conservator's examination}

This paper is a continuation of the article about history of the church shrouded in legend, entitled "Saint Nicolas' Church on the Czwartek Hill in view of historical resources", which was published in the second issue of the Portfolio of the Commission of Architecture, Urban and Landscape Studies of the Polish Academy of Sciences PAN Division in Lublin as of 2016.

\section{Introduction}

The main goal of this work is trail to define transformations phase and answer to question if the church was built in the period of prince Mieszko I and if it can be connected with Orthodox Church baptism of Poland.

Despite legends on the raise of the church in X century and fact, that it was second parish in Lublin, the building was avoided by historians, architects, conservators and archaeologists. The reason of that was not unwillingness, but lack of possibility. This situation began to change in recent years, but there is still a lot of things to do in order to finally state if Christianity had begun in Lublin at the Czwartek Hill.

Until present times, only a few research works have been carried out directly at the church building:

1961 - Scientific documentation of exploratory archaeological examinations performed by Marta Młynarska-Kaletyn, in 1961 in Saint Nicolas' Church within the framework of the research program of the Department of Architecture of Maria Curie Skłodowska University in Lublin upon the recommendation of Henryk Gawarecki, 
Voivodeship Monuments Conservator [1]. Two archaeological excavations were carried out (around the church) and the documentation was prepared as late as in 2013 by S. Hoczyk (after 52 years). These are the only archaeological works realized in the object up to 2018 , when foundations had been repaired. ${ }^{1}$

In later period, despite led renovations works, changing the façade plaster into the cement based, changing the roof after the fire, no research works were conducted. The first documented research works were realized in 1993, when W. Koziejowski, uncovered $17^{\text {th }}$-century plasters with additionally preserved layers of paintings, bossage on pilasters, Apostles' crosses, colour scheme of the vaulting and ribbing [2]. The reconstruction of the interior decoration has been completed in 2018. Several interesting discoveries were made during the works. Nave polychromy and most probably presbytery pilasters were made until $1632^{2}$. A small fragment of a signature "J. Jarosz AD 1628" was also discovered in the presbytery, which demonstrates that the interior was given its decoration during one period that lasted for a relatively long time. What is more, it was of particular importance to prove that the current nave vaulting was performed in its present form and attached to the choir loft wall and not to the façade.

Subsequent examinations, this time with the use of georadar, were made in 2014. Their included the interior together with the nearest vicinity of the church. The research showed that within the entire area no land untouched by a human was found. A number of anomalies were reported, which show the possibility of existence of vaulted areas below the church nave ( 3 crypts under the choir loft with the exit leading down to them from the nave) as well as a crypt which seems to constitute the extension of the presbytery crypt [3].

The first architectural studies in a limited range were performed in 2016. They included the church façade, the level of crypts, attic and two levels of the choir loft. The rest of the church was excluded from the research. The second activity undertaken within this period consisted of architecture and monument recording, referring to all levels of the building (crypts, basement, floors, attic) ${ }^{3}$. This analysis, even if to a limited range, made it possible to specify the phases of modifications of the church or determine the spots for archaeological examinations, which could prove that the church in its current form was based on older buildings [4].

In 2016, research on the façade was carried out in order to determine the original colours, which showed partially preserved older lime plasters which could date back to the period of establishment of the church [5].

Apart from research works, renovation began in 2009, aimed at restoring the interior decoration of the church, which, as it turned out later, dated back to the $17^{\text {th }}$ century, together with altar conservations, etc. It was a large-scale renovation divided into several stages and performed by different people. In 2016, the gallery under the choir loft was renovated and the choir loft in 2018. Renovation of the façade and anti-moisture isolation of the foundations began in 2018.

\section{Transformation phases}

Research methodology was leaning on interdisciplinary synthesis results of architectural, archaeological, conservatory studies, georadar examinations, $3 d$ scan and archival inquiry.

Basing on the results of the collected research, own observations as well as historical data, an attempt was made stratification of the building. This stratification can be divided to time after the construction of the church in its current form, which is clear without any major doubts, and to the period before the construction of the church in its current form, where, in practice, it is possible only to ask questions, which could be answered exclusively basing on examinations, mainly of an archaeological character.

1 The renovation which is currently in progress was supposed to include the isolation of foundations under archaeological supervision, but we already know that these works are not going to be performed, or their initial scope is going to be limited.

2 The inscription was preserved under the form of a fragment of the second number, assuming that it was a " 6 ", the entire third number and a fragment of the fourth one.

3 Records to which experts referred so far dated back to 1928 and did not include with its scope all levels. 


\section{Phase before the construction of the church in its current form}

Three objects, which do not match the construction and arrangement of the church building, were specified within the structure of the buildings, together with one specified based on the differences in materials and rapports in the nodes (Fig. 11).

1. The object is situated between the sacristy and the fencing. It extends beyond the outline of the church and it had assuredly formed the basement of the building, which does not exist nowadays (it is possible that its overground part was preserved, used as a fragment of fencing). We know that the basement could not have been made by drilling method, but through large-surface excavation. Additionally, it seems that the current presbytery wall was erected on its corner. It would have been impossible to locate this space/ building if church presbytery had been present both from a functional and technical side, and thus it can be assumed that it might have been demolished, for example, during the construction of presbytery walls.

2. The most mysterious part of the church building, which requires much deeper studies. In the $17^{\text {th }}$ and $18^{\text {th }}$ century, an additional residential level had been situated over the sacristy. It has not been established whether the two-level building was located here before the erection of the church in its current form. We know for sure that the wall between the presbytery and sacristy is 76 centimetres thick and it is deprived of pilasters (the presbytery includes pilasters and the core of the wall is $80-90 \mathrm{~cm}$ thick). The opening leading to presbytery was preserved on the first level (currently covered by vault resistance), which resembles an embrasure more than a window. ${ }^{4}$ However, the most unusual part of the sacristy is formed by its northern wall, the course of which differs from the outside and from the inside (what is more, the currently dug out wall crowning/offset below the wall is also characterised by a diversified course - Fig.9). We also know that in the middle of the wall thickness, at the basement level, the wall gets stratified, but it was impossible to determine which one was attached to which. The uncovered part below the level of ground was performed simultaneously with the external part of the wall (it was initially 76-96 centimetres thicker). It only remains unknown why the thickness of the wall was reduced so much instead of demolishing it and constructing it again. It can for sure be stated that this procedure was laborious, time-consuming and backbreaking considering the reality of those times. ${ }^{5}$ Before being reduced, the wall was ca. $350 \mathrm{~cm}$ thick, and at the ground floor level, its thickness amounted to $220 \mathrm{~cm}$. Solving the problems of thickness this wall, should be made by archaeological excavations, maybe should by possibly to determined their function.

3. Presbytery crypt. The arrangement of the presbytery walls at the level of the basement differs from the one on the ground floor both when it comes to the arrangement itself as well as to its location. Distinct stratification is visible in the southern wall, unveiling the connection of two walls, but it was impossible to specify whether the wall of the current presbytery was added here subsequently or else it had been the opposite course of events. It seems that the walls at the basement level determine the shape of the older church, which was demolished during the construction of the already existing structure, but this assumption would be possible to confirm only after performing at least flooring excavations.

4. Gallery under the choir loft. It seems that here, another object existed within the basement parts, which could have been preserved exclusively under the ground or in some parts of the over-ground section. Unfortunately, in this case, due to the existing buttresses, pilasters and choir loft arcade, which cover the nodes and walls of the object, the only information possible to be achieved will come from archaeological excavations.

4 Window openings and spaces adjacent to the presbytery were sometimes present, serving the function of an oratory or infirmary, but this should be assigned to monasteries. However, these windows were bigger, which we have learnt from historical research and information, as it used to happen that a person praying or listening to the mass would fall through these windows.

5 At the moment of the examinations being conducted, both the mortar as well as bricks were characterized by high resistance and the task to deconstruct such a wall would constitute an important challenge even with the use of modern techniques and tools. 


\section{Phase after the construction of the church in its current form}

\section{Phase $\mathrm{a}-15^{\text {th }}-16^{\text {th }}$ century}

During this period, the general structure of the church would not significantly differ from the current one. It is possible that nave division had already existed, however, exclusively at the basement level. A wooden ceiling could be found in the presbytery, sacristy and nave (described as seriously damaged in 1603). The northern and southern walls included 3 windows each. Residential spaces had probably been functioning during this phase over the sacristy.

\section{Phase $b$ - late $16^{\text {th }}$ century}

In this phase, the nave, together with the presbytery, probably had a timber ceiling; the choir loft was erected following the present division, but still with timber coffered ceiling, during the erection of which the existing windows of the last span were bricked up or reduced. Sacristy constituted the only element in the church having its vaults. The interior of the church was plastered and painted and it had most probably been similar when it comes to the church façade.

\section{Phase c - until 1630}

This phase consisted of gradually conducting the works connected with increasing the prestige of the church. The wooden ceiling in the presbytery was replaced with brick vaulting. Pilasters were added from the inside and outside in place of the resistance elements in order to stabilise the walls. In the presbytery, the vaulting was ornamented with stucco bars and the walls were given their current ornamentation. The inscription "J. Jarosz AD 1628" was uncovered during the conservation works and thus it can be assumed that Jan Jaroszewicz had probably been the author of the works. Within this phase, the timber ceiling of the gallery under the choir loft was probably replaced with vaulting and Piotr Traversii had probably been the author, and for sure the funder, of this undertaking.

\section{Phase d - 1630-1650}

This phase is directly connected with the activity of priest Turobojski and preparations for establishing the second Lublin parish in the church. During this period, the timber ceiling over the nave was replaced by current decoration (1632). This construction made it automatically necessary to perform buttresses from the outside and pilasters from the inside. A wall separating the nave was also erected, elevated up to the level of the attic. At that time, the gallery under the choir loft served the function of a porch with three entrances from the outside and one axis passage leading to the nave. The entrance to the choir loft was situated in the same place as the current one, but it was performed with the use of brick and mortar, vaulted and including the straight flight of stairs and not spiral staircase as it is currently the case. The choir loft was given its vaulting, and for the purpose of its construction, it was necessary to divide the nave into two parts. Apart from the choir, this place must have included the described spaces for church brotherhoods.

\section{Phase e - before 1781}

The $18^{\text {th }}$ century was not favourable for the church on the Czwartek Hill. A bad technical condition, no clergyman permanently managing it as well as no equipment clearly demonstrate that, due to negligence or unspecified disaster or catastrophe, it remained nearly in the state of ruin (the bad condition continued inside and outside the building). The current chapel had already existed at that time, serving the function of a porch. Before 1781, the church was renovated, the residential section over the sacristy was removed and a new façade gable was constructed with brick and mortar, while the vaulting over the choir loft was deconstructed and a number of works were performed in order to strengthen and stabilise the structure of the building. It is possible that Kajetan Szeptycki, buried in the crypts, was the founder of the works or of a part of them.

\section{Phase $f$ - from the beginning of the $20^{\text {th }}$ century}

Ongoing renovations and conservations were performed in the $19^{\text {th }}$ century and the belfry was constructed from the southern side. The church was no longer a parish, which had an important influence on its technical condition and prestige. The renovation conducted in the years 1874-76 thanks to the involvement of Mikołaj 
Hajko probably contributed to modifying the roof arrangement and to giving the façade gable its current decoration. The church was painted with orange accents (discovered within the conservation works). In the early $20^{\text {th }}$ century, during the next change of the function of the church to serve as a parish, a porch was made from the western side, with a simultaneous transformation of the old porch into the current chapel, changing the communication scheme, replacing timber flooring with terracotta as well as introducing new equipment, changing the shape of the ridge turret, etc.

\section{Conclusions}

Basing on the analyses and the material gathered, it was possible to determine the phases of the transformation of the current building of the church. It turned out that it had been erected in a more homogenous way than it was assumed. Presbytery together with three-span nave (and not two-span as it was assumed until now) were constructed at the same time. It was impossible to determine whether the sacristy was already present within this phase and the church was added to it or else the situation was a little different. The next phases were connected with replacing the timber ceilings with vaulting or with conducting reconstruction after more serious damages.

Unfortunately, the most important conclusion is fact, that no object was found that could confirm the legend of the establishment of the church in the $10^{\text {th }}$ century. Most probably, if it had existed then, the only traces should be searched under the ground by archaeologists in cooperation with architects. There exists some possibility that the structure of the sacristy could include traces dating before the $15^{\text {th }}$ century, but this should be determined in further research. An additional question that should be answered is the space over the sacristy and its function, more precisely whether it had been connected exclusively with the church or was it assigned a sacred function at a later time. Finding the answers to the questions quoted above would be of major importance for the church, the hill and the city of Lublin. However, taking into consideration the current situation of the parish, without involving external staff and funds, we will not find the answers to such questions for sure. We can only hope that what was achieved within the last few years is not going to be postponed and we will not have to wait for the continuation of the research for the next 50 years.

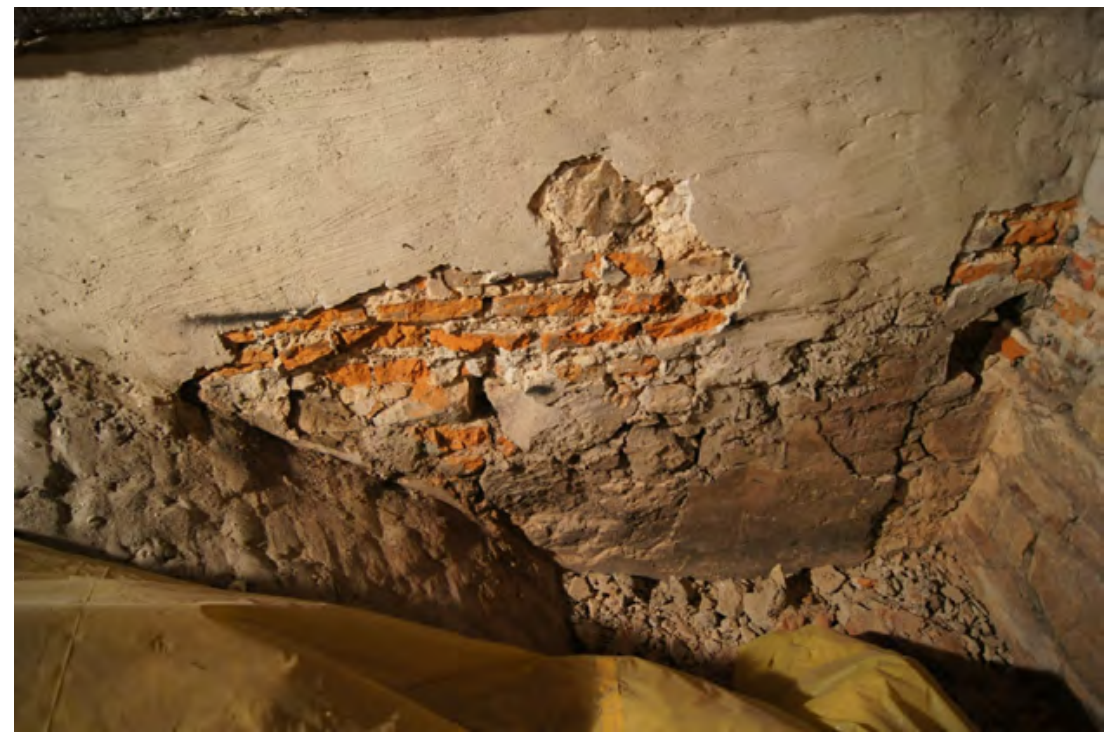

Fig. 1. View of the chancel wall from the attic over the nave with plaster relics visible, to which current vaulting was added 


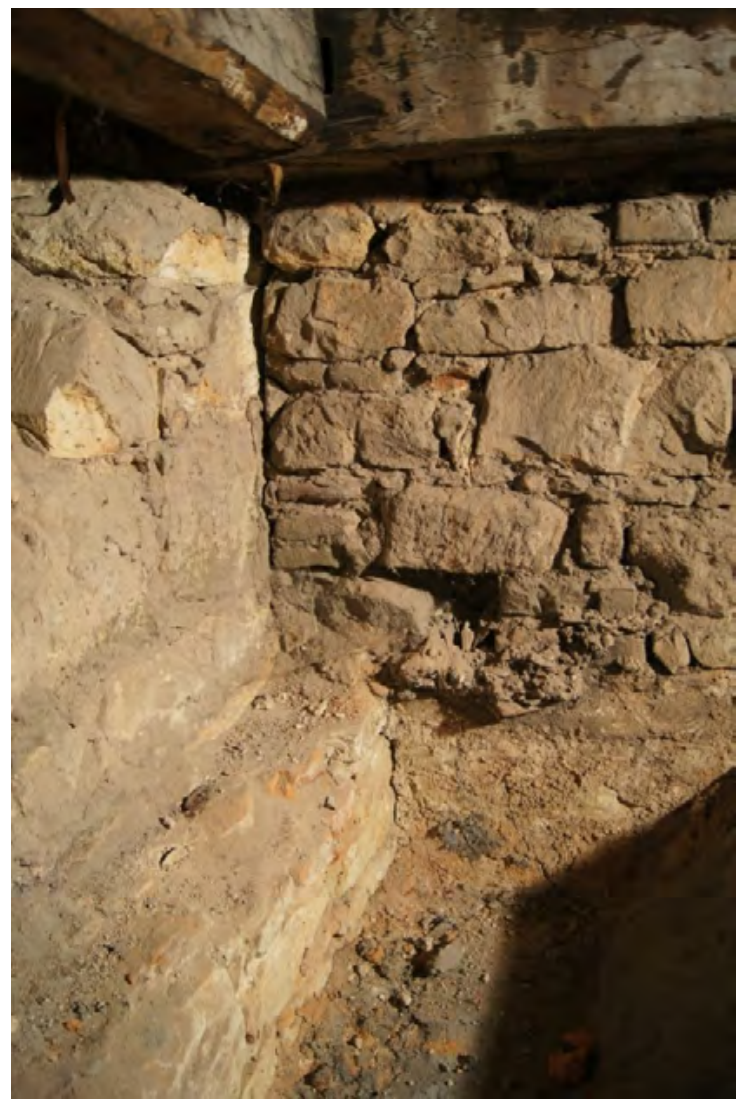

Fig. 2. View of the chancel wall from the level of the attic over the presbytery with the chancel wall visible, added to the southern wall of the presbytery

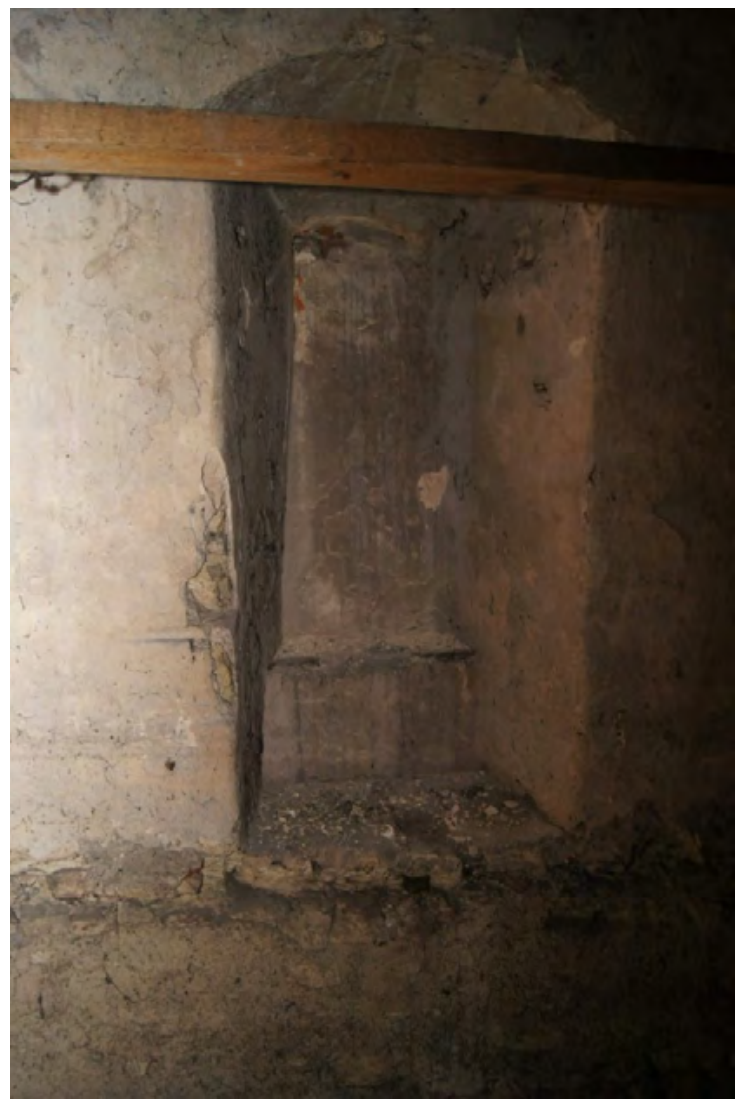

Fig. 3. Northern wall of the presbytery, view from the attic over the sacristy with the opening leading to the presbytery visible

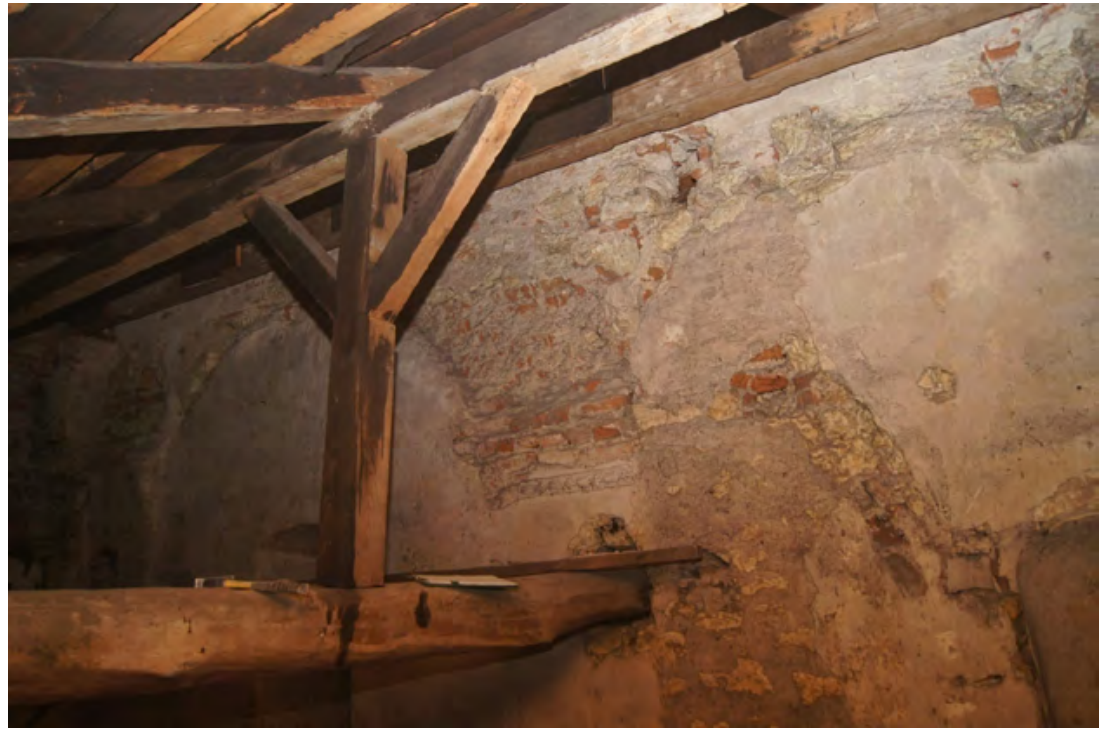

Fig. 4. Northern wall of the presbytery, view from the attic over the sacristy with the negative after two vaulting lunettes visible 

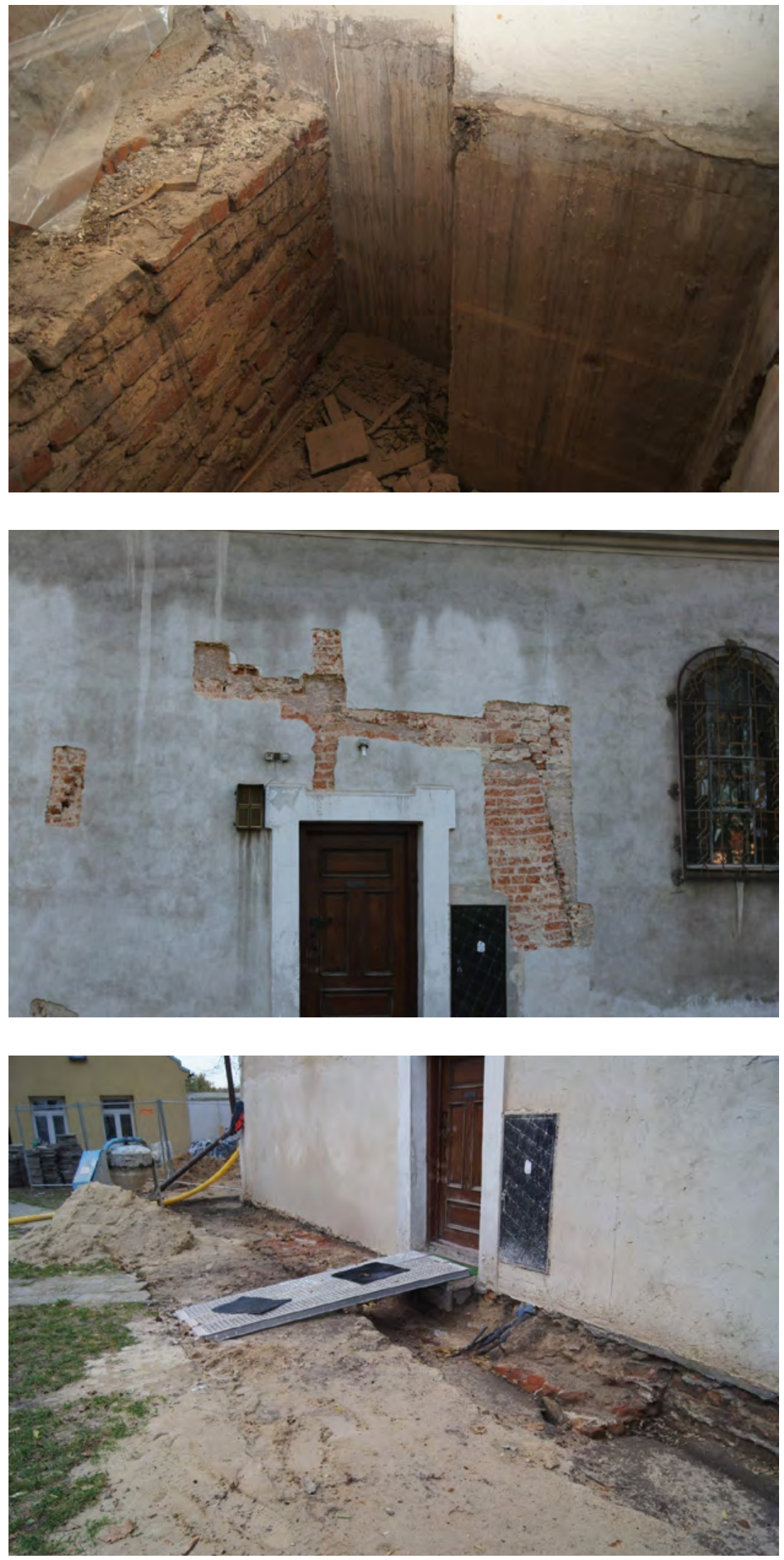

Fig. 5. Discovered paintings of nave walls and pilasters after removing the floor of choir loft arcade

Fig. 6. Uncovered buttress edge of the northern sacristy wall

Fig. 7. Wall discovered in the excavation of the northern sacristy wall 

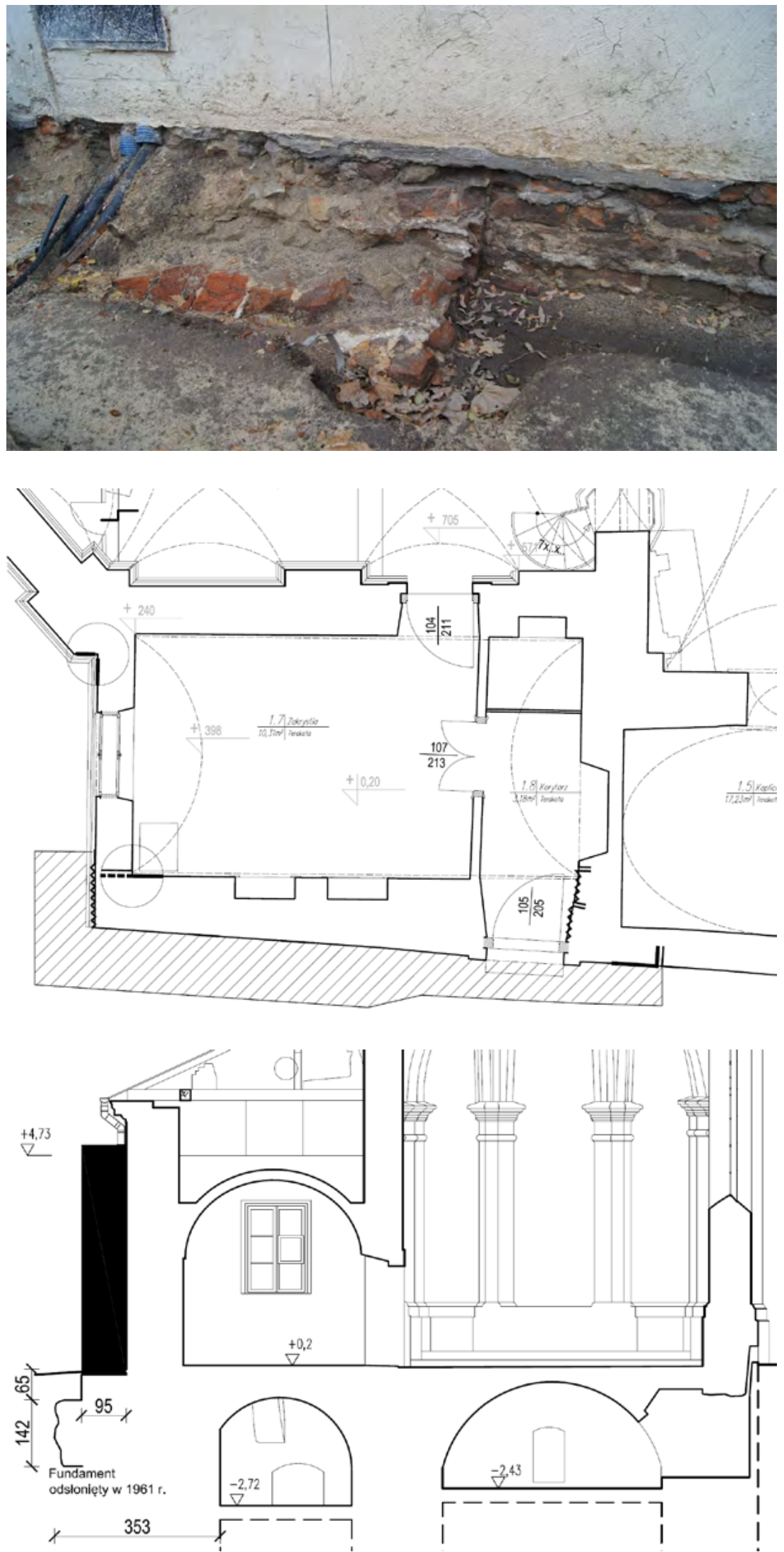

Fig. 8. Wall discovered in the excavation of the northern sacristy wall

Fig. 9. Plan of the ground floor of the sacristy, brick wall below the land level was marked with hachure

Fig. 10. Cross-section of the presbytery and sacristy (location of the removed sacristy wall was marked in black) 

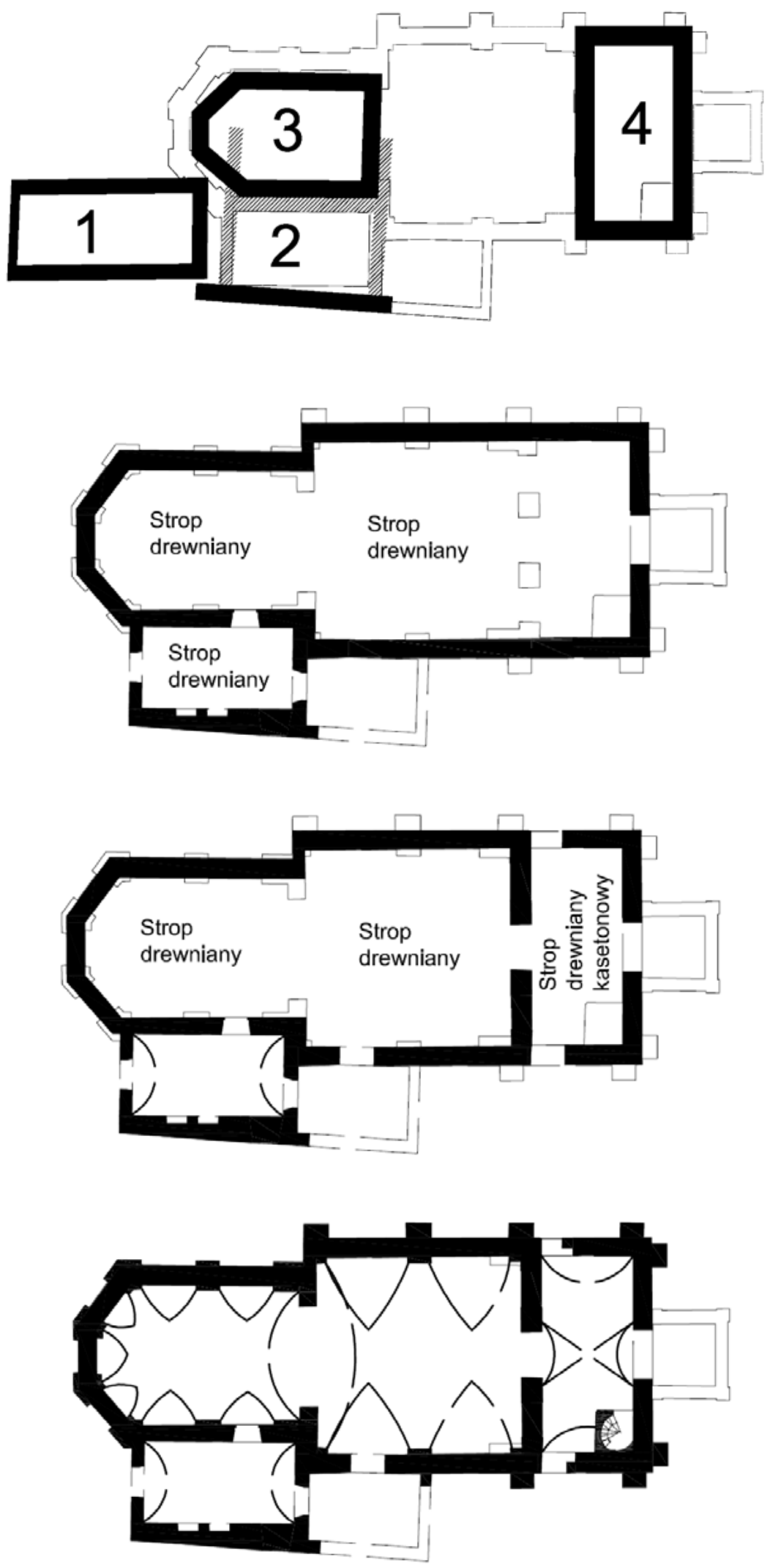

Fig. 11. Location of objects on which the church in its current form could have been constructed

Fig. 12. Phase $a, 15^{\text {th }}-16^{\text {th }}$ century

Fig. 13. Phase $b$ - late $16^{\text {th }}$ century

Fig. 14. Phase $d-1630-1650$ 


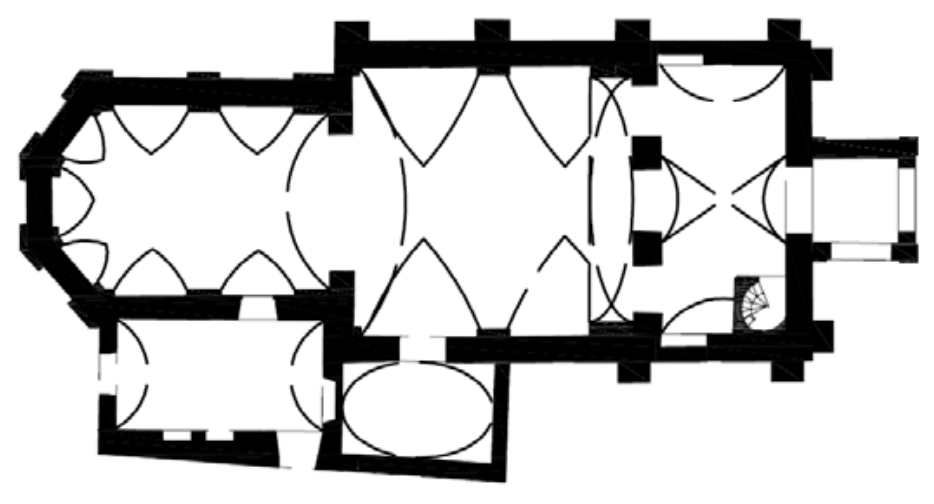

Fig. 15. Phase $f-$ early $20^{\text {th }}$ century

\section{Literature}

[1] Młynarska-Kaletyn M. (1961), Hoczyk S., 2013, Dokumentacja naukowa sondażowych badań wykopaliskowych przeprowadzonych przez mgr Martę Młynarską-Kaletyn w roku 1961 przy kościele św. Mikołaja w ramach programu badawczego katedry Archeologii UMCS na zlecenie Wojewódzkiego Konserwatora Zabytków mgr Henryka Gawareckiego (Scientific documentation of exploratory archaeological examinations performed by Marta Młynarska-Kaletyn, M.A., in 1961 by Saint Nicolas' Church within the framework of the research program of the department of Architecture of Maria Curie Skłodowska University in Lublin upon the order of Henryk Gawarecki, M.A., Voivodeship Monuments Conservator).

[2] Koziejowski W., 1993, Badania sondażowe warstw malarskich kościoła św. Mikołaja na Czwartku w Lublinie (Exploratory tests of painting layers of Saint Nicolas' Church on the Czwartek Hill in Lublin).

[3] Janus K., 2014, Ekspertyza geofizyczna wnętrza i zewnętrza budynku kościoła pw. Św. Mikołaja na Czwartku w Lublinie (Geophysical evaluation of the interior and exterior of the building of Saint Nicolas' Church on the Czwartek Hill in Lublin).

[4] Janus K., Stankiewicz T., 2016, Badania architektoniczne kościoła św. Mikołaja na Czwartku (Architectural examinations of Saint Nicolas' Church on the Czwartek Hill in Lublin).

[5] Konkolewską M., 2016, Wyniki badań sondażowych elewacji kościoła św. Mikołaja na Czwartku w Lublinie (Results of exploratory tests in the façade of Saint Nicolas' Church on the Czwartek Hill in Lublin).

[6] Stolarz B., 2014, Wiadomości konserwatorskie, Realizacje prac konserwatorsko-restauratorskich we wnętrzu kościoła parafialnego św. Mikołaja w Lublinie (Conservator's news, Realizations of conservation and restoration works in the interior of Saint Nicolas' Parish Church in Lublin). 